\title{
Spatiotemporal variation of mosquito diversity (Diptera: Culicidae) at places with different land-use types within a neotropical montane cloud forest matrix
}

Carlos Antonio Abella-Medrano ${ }^{1,2}$, Sergio Ibáñez-Bernal ${ }^{1}$, lan MacGregor-Fors ${ }^{1}$ and Diego Santiago-Alarcon ${ }^{2^{*}}$

\begin{abstract}
Background: Land-use change has led to a dramatic decrease in total forest cover, contributing to biodiversity loss and changes of ecosystems' functions. Insect communities of medical importance can be favored by anthropogenic alterations, increasing the risk of novel zoonotic diseases. The response of mosquito (Diptera: Culicidae) abundance and richness to five land-use types (shade coffee plantation, cattle field, urban forest, peri-urban forest, well-preserved montane cloud forest) and three seasons ("dry", "rainy" and "cold") embedded in a neotropical montane cloud forest landscape was evaluated.
\end{abstract}

Methods: Standardized collections were performed using 8 CDC miniature black-light traps, baited with CO2 throughout the year. Generalized additive mixed models were used to describe the seasonal and spatial trends of both species richness and abundance. Rank abundance curves and ANCOVAs were used to detect changes in the spatial and temporal structure of the mosquito assemblage. Two cluster analyses were conducted, using $1-\beta$ sim and the Morisita-Horn index to evaluate species composition shifts based on incidences and abundances.

Results: A total of 2536 adult mosquitoes were collected, belonging to 9 genera and 10 species; the dominant species in the study were: Aedes quadrivittatus, Wyeomyia adelpha, Wy. arthrostigma, and Culex restuans. Highest richness was recorded in the dry season, whereas higher abundance was detected during the rainy season. The urban forest had the highest species richness $(n=7)$ when compared to all other sites. Species composition cluster analyses show that there is a high degree of similarity in species numbers across sites and seasons throughout the year. However, when considering the abundance of such species, the well-preserved montane cloud forest showed significantly higher abundance. Moreover, the urban forest is only $30 \%$ similar to other sites in terms of species abundances, indicating a possible isolating role of the urban environment.

Conclusion: Mosquito assemblage was differentially influenced by land-use change and seasonality, but at the same time the assemblage is rather homogeneous across the studied landscape, suggesting a high degree of spatial connectivity. Information generated in this study is potentially useful in the development of urban planning and surveillance programs focused mainly on mosquito species of medical and veterinary importance.

Keywords: Culicidae, Landscape, Land-use changes, Diversity, Anthropogenic effects, Urban ecology, Urban parasitology

\footnotetext{
* Correspondence: diego.santiago@inecol.mx

${ }^{2}$ Instituto de Ecología A.C., Red de Biología y Conservación de Vertebrados,

Carretera antigua a Coatepec 351 El Haya, Xalapa 91070, Veracruz, Mexico

Full list of author information is available at the end of the article
}

(c) 2015 Abella-Medrano et al. Open Access This article is distributed under the terms of the Creative Commons Attribution 4.0 International License (http://creativecommons.org/licenses/by/4.0/), which permits unrestricted use, distribution, and reproduction in any medium, provided you give appropriate credit to the original author(s) and the source, provide a link to the Creative Commons license, and indicate if changes were made. The Creative Commons Public Domain Dedication waiver (http://creativecommons.org/publicdomain/zero/1.0/) applies to the data made available in this article, unless otherwise stated. 


\section{Background}

Land-use change has led to a dramatic decrease of total forest cover and an increasing isolation among forest remnants, contributing to the current biodiversity loss, rising species extinction rates, and alterations of key functional properties of ecosystems [1-3]. For instance, changes in land-use and vegetation cover have caused a decline of bird diversity $[4,5]$ and of butterfly species in scrub forests, wetlands, and dry grassland $[5,6]$. The abundance and species richness of some rodents depend on shrub vegetation that provides refuge and food, for this reason their diversity is lower in rangelands [7]. Thus, alterations of mosquito diversity by changes in land uses may disrupt the transmission dynamics of emerging and re-emerging zoonotic infectious diseases [8].

Studies on the effect of land-use changes on insect communities of medical importance (e.g., mosquitoes) are scarce, but in general show that anthropogenic alterations positively affect insect vector populations by creating favorable breeding conditions [9-11]. Land-use change has been repeatedly mentioned as an anthropogenic factor that exacerbates mosquito-borne diseases [12]. For example, clearing land for subsistence agriculture, dam construction for hydroelectric power or recreational use, often expands and creates new mosquito breeding habitats, facilitating the introduction of invasive species or allowing mosquito populations to rise, increasing the probability of disease transmission [9, 13, 14]. Moreover, the quantification of vector population responses to different degrees of anthropogenic disturbances is virtually nonexistent. Hence, how insect vector communities respond to alterations of the landscape is relevant to understanding the emergence of zoonotic pathogens $[15,16]$.

In this study we focused on understanding the responses of mosquito (Diptera: Culicidae) species richness and abundance, as well as their community structure and composition to different land use types. Our study was conducted in a region that was originally dominated by neotropical montane cloud forest. We expected to find a decline in mosquito diversity from preserved to urban forests due to homogenizing conditions (e.g., simplified habitat structure, more resources for anthropophilic mosquito species, breeding sites such as cans, tires) of cities that usually favor a few urban adapted species. Hence, higher mosquito diversity is expected in the well-preserved cloud forest due to its more natural and complex composition (i.e., well-defined vegetation layers) compared to simplified land types (e.g., shade coffee plantation, cattle field). We expected a similar community structure and composition among sites with similar vegetation structure (i.e., well-preserved cloud forest, periurban and urban forest) due to the high connectivity across the studied landscape. The study was performed in three defined seasons ("dry", "rainy" and "cold") of the year; higher mosquito richness and abundance during the rainy season was expected because environmental conditions (i.e., higher temperature and humidity) are more conducive for insect development.

\section{Methods}

Study area

The study was conducted in an area located in the central portion of the state of Veracruz, Mexico, where the original vegetation was montane cloud forest as described by Rzedowski (1978) (Fig. 1). The original vegetation has been heavily fragmented and there are a few isolated remnants within a matrix composed mostly of shade coffee plantations, cattle fields, and human settlements that are rapidly expanding [17-19]. According to the description of Contreras \& Ornelas (1999), the well-preserved montane cloud forest present a mean annual rainfall on $1492 \mathrm{~mm}$, with a minimum of $44.8 \mathrm{~mm}$ in December and a maximum of $273.4 \mathrm{~mm}$ in June. Mean annual temperature is $18{ }^{\circ} \mathrm{C}$, with a maximum mean temperature of $20.4{ }^{\circ} \mathrm{C}$ in May and a minimum of $14.9^{\circ} \mathrm{C}$ in January [20]. We sampled five sites, each with a different land-use type: 1) well-preserved montane cloud forest (CF), 2) urban forest (UF), 3) peri-urban forest (PF), 4) shade coffee plantation (CS), and 5) cattle field (PS) (Fig. 1).

The well-preserved montane cloud forest (CF) is located in the municipality of Xico, bordering Coatepec $\left(19^{\circ}\right.$ $27^{\prime} 15^{\prime \prime} \mathrm{N}, 97^{\circ} 00^{\prime 2} 28^{\prime \prime W}$; 1300-1500 masl). The floristic composition of this site is similar to that of other fragments of cloud forest in the region with the following dominant species: Quercus affinis, Q. salicifolia, Q. leiophylla, Liquidambar styraciflua, Alchornea latifolia, Clethra mexicana, Myrsine coriaceae, Cinnamomum effusum, Vismia mexicana, Ilex sp., Eugenia sp., Ailanthus altissima, Turpinia insignis, Heliocarpus appendiculatus, Persea americana, Persea schiedeana [21].

The urban forest (UF) (Park Molinos de San Roque) is a small urban natural protected area (15 ha) located in northwestern portion of the city of Xalapa $\left(19^{\circ} 33^{\prime} 07^{\prime \prime} \mathrm{N}, 96^{\circ}\right.$ $56^{\prime} 18^{\prime \prime W}$; 1427-1467 masl). This area retains much of its original cloud forest vegetation, with some small areas of second growth vegetation and an artificial swamp. Dominant species include: Quercus xalapensis, Liquidambar macrophyla, Carpinus caroliniana, C. mexicana, Bocconia frutescens, Piper auritum, Ricinis communis, Melampodium divaricatum, Trichilia havanensis, Cynodon plectostachtyum, Typha dominguensis, Juncus sp., and Ciperus sp. $[22,23]$.

The peri-urban forest (PF) (Ecologic Park Francisco Xavier Clavijero) is located in the southwestern border of the city of Xalapa, which is rapidly expanding $\left(19^{\circ} 30^{\prime} 52^{\prime \prime} \mathrm{N}\right.$, 96 $56^{\prime} 12^{\prime \prime W}$; 1344-1372 masl). Vegetation consists of second growth vegetation and abandoned coffee plantations. Some characteristic plants of this site are: Quercus germana, Q. xalapensis, Platanus mexicanus, L. macrophyla, 


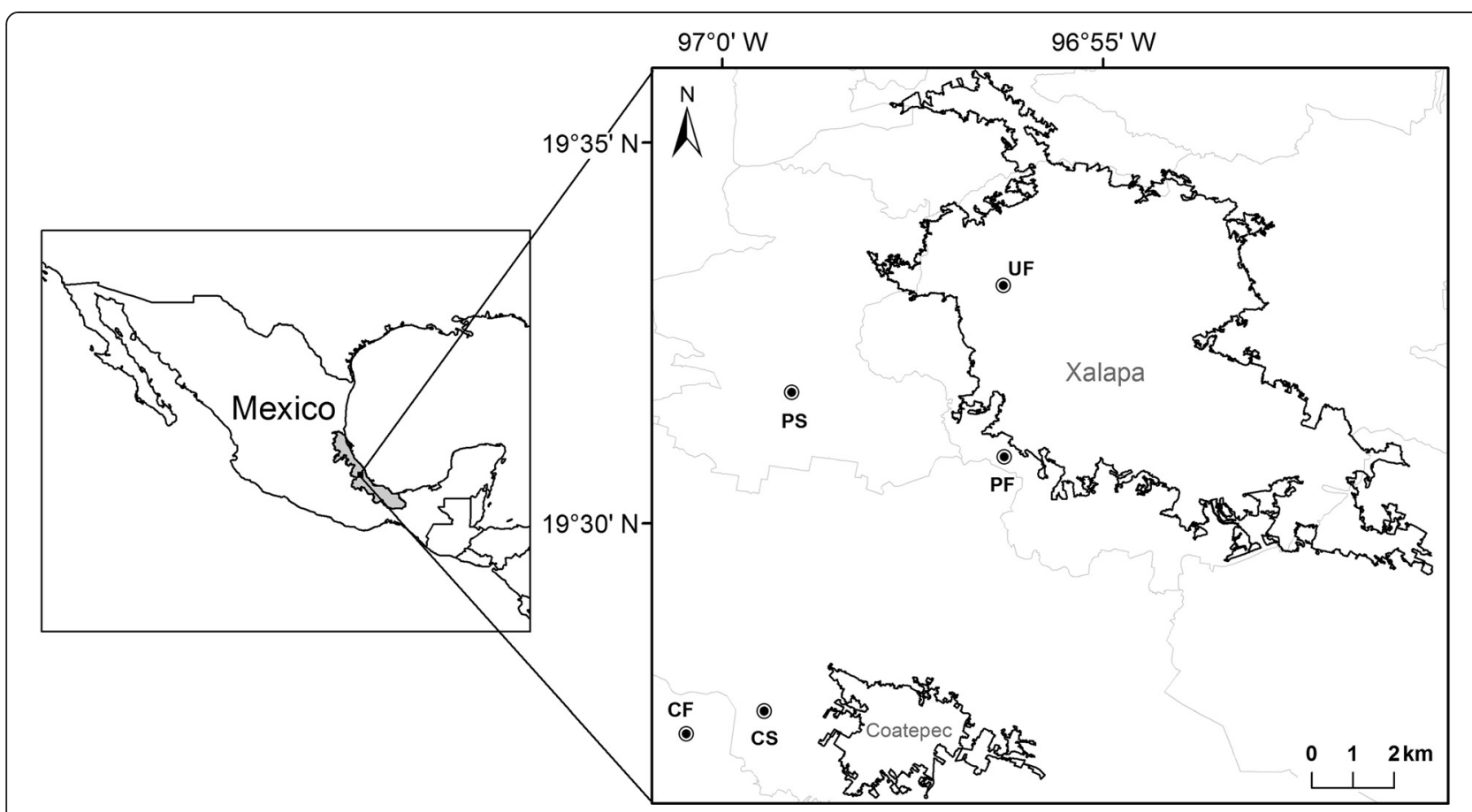

Fig. 1 Study area and sampling sites (circles with central dot). Black lines indicate the limits of urban areas and gray lines the municipality borders. Sites: well-preserved montane cloud forest (CF), peri-urban forest (PF), urban forest (UF), shade coffee plantation (CS) and cattle field (PS)

C. caroliniana, Cinnamomum effusum, Ocotea sp., Turpinia insignis, C. mexicana, Eugenia xalapensis, Lonchocarpus sp., Meliosma alba, Ilex tolucana, Oreopanax xalapensis, and Palicourea padifolia $[17,18]$.

The shade coffee plantation (CS) is located in the municipality of Xico, bordering Coatepec $\left(19^{\circ} 27^{\prime} 32^{\prime \prime} \mathrm{N}\right.$, 96 59'26"W; 1210-1313 masl). The coffee plantation is characterized by the presence of some cloud forest elements and also by some exotic plant species: Coffea spp., Inga jinicuil, P. americana, P. schiedeana, Heliocarpus appendiculatus, H. donnell-smithii, Rapanea myricoides, Trichilia havanensis, Leucaena leucocepaha, Malvaviscus arboreus, Palicourea padifolia, Piper nudum, Liquidambar styraciflua, Quercus spp., and Pinus patula [21-24].

The cattle field (PS) is located in the municipality of San Andrés Tlalnelhuayocan (19 31'37”N, 9659'7”W; 1460-1525 masl). As other cattle fields in the region, this site is open for grazing with scattered trees, shrubs, and herbs, surrounded by patches of cloud forest and second growth vegetation. Predominant scattered tree and shrubs species include: P. mexicanus, Quercus sp., L. macrophyla, Acacia pennatula, Psidium guajava, Cnidoscolus sp., Piper sp. (pers. obs.). The herbaceous stratum is dominated by native short grasses (e.g. Axonopus compressus, Paspalum spp.), an exotic tall grass (Cynodon plectostachyus), and other species (e.g. Melampodium divaricatum, Borreria laevis, Hyptis atrorubens, Desmodium sp., Eupatorium sp.) [25].

\section{Vector sampling}

Sampling was conducted within a half-hectare square grid $(100 \times 50 \mathrm{~m})$ at each site using eight CDC miniature blacklight (UV) traps (model 1212; John W. Hock Company) baited with $\mathrm{CO}_{2}$ (Yeast; Saccharomyces cerevisiae). Traps were placed in two transects of 100 meters, separated 50 meters from each other (four traps per transect), with a distance of 30 meters between traps on the same transect to avoid competition between them; traps were placed at $60 \mathrm{~cm}$ from the ground. Traps were left active three hours during the morning (starting one hour before sunrise), at noon (from 12:30 to 15:30), and during late afternoon (one hour before sunset), for a total of nine hours of sampling per day; each site was sampled for two days each season. We used information provided by a global position system (Garmin GPSMAP 60) to determine the exact time of sunrise and sunset. Collected mosquitoes were sacrificed with chloroform gas, and then preserved in Petri dishes prepared with wax paper and cotton wool. Specimens were examined under a stereoscopic microscope and mounted on paper triangles held with entomological pins. We used different taxonomic publications for the identification of mosquito genera and species [25-34], reviewing the female external as well as male external and genitalia 
characteristics for identification. The identified mosquitoes were deposited into the entomological collection of the Institute of Ecology AC (IEXA, key 048.0198).

\section{Statistical analysis}

Species accumulation curves and the Abundance-based Coverage Estimator (ACE) and Chaol were used to determine sample efficiency [35-39]. This procedure was performed with EstimateS 8.2.0 [40].

Generalized additive mixed models (GAMM) were used to describe the spatiotemporal trends of both mosquito species richness and abundance. This statistical procedure is an extension of a generalized additive model which relaxes the assumption that the data are independent observations; hence, allowing for correlates, in our case each CDC miniature black-light (UV) trap [41]. An advantage of using GAMM to describe the abundance and richness at all studied seasons of the year and at the different sampling sites is that we can estimate the underlying trends of the data, without assuming that the trend has any specific functional form. Analyses were performed in R 2.15.3 ( R Development Core Team 2013), using the following packages: mgcv [42], nlme [43], lme4 [44], gamm4 [42], and lattice [45].

Rank abundance curves were used to detect changes in the spatial and temporal structure of the mosquito assemblage [37]. ANCOVAs were used to assess significant differences in the slope between abundance curves (comparing seasons and sites). Values were $\log 10$ transformed because mosquito species abundances differed widely among sampling sites, seasons, and species. Subsequently, ANOVA tests were used to identify the effect that sites and seasons had on mosquito abundances. This analysis has been used primarily to analyze bird communities; this is the first time it is used in mosquito diversity studies [46].

To evaluate species composition between sites and seasons multivariate cluster analyses using $\beta$ sim and the Morisita-Horn index were performed [37]. On the one hand, $\beta$ sim quantifies the relative magnitude of won and lost species relative to the sample with fewer unique species [47]. Therefore, $\beta$ sim allows the identification of changes in the composition of species; in this case for each land-use type and season. Because this is an analysis of dissimilarity we take $1-\beta \operatorname{sim}$. On the other hand, to analyze composition between sites and seasons using relative abundances, we performed a cluster analysis with the Morisita-Horn index that is a widely used species turnover index. It measures the probability that two randomly selected individuals, each from a different site or group, are of the same species [37]. The analysis and construction of the two clusters was performed in $\mathrm{R}$ v.3.0.2; the vegan and betadiver packages were used for the $\beta$ sim index and the vegdist for the Morisita-Horn index respectively.

\section{Results}

\section{Mosquito assemblage description}

A total of 2536 adult mosquitoes belonging to 9 genera and 10 species, captured during the dry, rainy, and cold seasons of 2014 were processed. All 10 species were recorded at the five studied conditions. The ACE index estimates 10 species, whereas the Chao1 index estimates 9 species, suggesting that $100 \%$ of the species were obtained in the present study (Additional file 1). The dominant species were Aedes quadrivittatus (36.16\%), Wyeomyia adelpha (37.78 \%), Wy. arthrostigma (16.88 \%), and Culex restuans (7.73\%). Among the rare species we found Coquillettidia perturbans, Anopheles eiseni, Uranotaenia geometrica, Mansonia titillans and Sabethes gymnothorax, which together represent $1.46 \%$ of the sample (Table 1). Specimens of Aedes (Ochlerotatus) genus were not determined to the species level because only females were captured and male genitalia are required for species determination, but they were included in the study. The highest richness was recorded during the dry season (9 spp.), followed by the cold (8 spp.) and rainy seasons (7 spp.). In contrast, abundance was highest during the rainy season (1345 specimens), followed by the dry (671 specimens) and the cold seasons (520 specimens) (Table 1 ).

\section{Richness analysis}

Significant effects of both seasons of the year and landuse type on species richness were observed (Table 2). The highest richness was found during the dry season (Table 2). For land use types, the well-preserved cloud forest (CF) and the shade coffee plantation (CS) had significantly lower species numbers in comparison to the urban forest (UF) (Table 2). UF had the highest richness (8 spp.) as compared with all other sites, which had 6 species each. Significant interaction effects between seasons and land-use types were detected, where CS and the peri-urban forest (PF) had higher species richness during the rainy season and UF had highest richness during both rainy and dry seasons (Table 2).

\section{Abundance analysis}

Significant effects of land-use type on species abundances were detected, but only a non-significant trend of seasonality during the dry season (Table 2). All sites (PF, UF, CS and cattle field (PS)) show statistically significant lower mosquito abundances in comparison to CF (Table 2). CF had a total of 1231 individuals, followed by PF (467), UF (459), CS (321), and PS (55). There were significant positive interaction effects between season and land-use type on mosquito abundances; higher abundances were recorded at PF and CS during the rainy season, and at UF during the dry season (Table 2). 
Table 1 Mosquito species numbers captured at each land-use type and seasons in the study area. Species codes on the first column are used in other tables and figures

\begin{tabular}{|c|c|c|c|c|c|c|c|c|c|c|c|c|c|c|c|c|c|}
\hline \multirow[t]{2}{*}{${ }^{a} \mathrm{C}$} & \multirow[t]{2}{*}{ Species } & \multicolumn{5}{|l|}{ Dry } & \multicolumn{5}{|c|}{ Rainy } & \multicolumn{5}{|c|}{ Cold } & \multirow[t]{2}{*}{ TOTAL } \\
\hline & & $\overline{C F}$ & PF & UF & CS & PS & $\mathrm{CF}$ & PF & UF & CS & PS & $\overline{C F}$ & PF & UF & CS & PS & \\
\hline $\mathrm{Aq}$ & Aedes (Howardina) quadrivittatus (Coquillett, 1902) & 163 & 15 & 1 & 48 & 4 & 374 & 11 & 4 & 85 & 1 & 204 & 1 & 1 & 3 & 2 & 917 \\
\hline $\mathrm{Cr}$ & Culex restuans (Theobald, 1901) & 8 & 35 & 73 & 5 & 3 & 11 & 14 & 24 & 8 & 2 & 1 & 0 & 7 & 2 & 3 & 196 \\
\hline Wa & Wyeomyia adelpha (Dyar and Knab, 1906) & 30 & 24 & 31 & 2 & 8 & 205 & 215 & 13 & 147 & 10 & 213 & 42 & 1 & 13 & 4 & 958 \\
\hline Wt & Wyeomyia arthrostigma (Lutz, 1905) & 17 & 18 & 160 & 1 & 3 & 0 & 83 & 121 & 7 & 6 & 2 & 2 & 7 & 0 & 1 & 428 \\
\hline A & Aedes (Ochlerotatus) sp. & 0 & 0 & 9 & 0 & 0 & 0 & 0 & 0 & 0 & 0 & 0 & 2 & 0 & 0 & 0 & 11 \\
\hline Ug & Uranotaenia geometrica (Theobald, 1901) & 1 & 4 & 0 & 0 & 1 & 0 & 0 & 0 & 1 & 0 & 0 & 0 & 0 & 1 & 6 & 14 \\
\hline$C p$ & Coquillettidia perturbans (Walker, 1856) & 0 & 1 & 3 & 0 & 0 & 0 & 0 & 1 & 0 & 0 & 0 & 0 & 0 & 0 & 1 & 6 \\
\hline $\mathrm{Ae}$ & Anopheles eiseni (Coquillett, 1902) & 2 & 0 & 0 & 0 & 0 & 0 & 0 & 0 & 0 & 0 & 0 & 0 & 0 & 1 & 0 & 3 \\
\hline Mt & Mansonia titillans (Walker, 1848) & 0 & 0 & 0 & 0 & 0 & 0 & 0 & 2 & 0 & 0 & 0 & 0 & 0 & 0 & 0 & 2 \\
\hline \multirow[t]{3}{*}{$\mathrm{Sg}$} & Sabethes gymnothorax (Harbach and Petersen, 1992) & 0 & 0 & 1 & 0 & 0 & 0 & 0 & 0 & 0 & 0 & 0 & 0 & 0 & 0 & 0 & 1 \\
\hline & Abundance & 221 & 97 & 278 & 56 & 19 & 590 & 323 & 165 & 248 & 19 & 420 & 47 & 16 & 20 & 17 & 2536 \\
\hline & Richness & 6 & 6 & 7 & 4 & 5 & 3 & 4 & 6 & 5 & 4 & 4 & 4 & 4 & 5 & 6 & 10 \\
\hline
\end{tabular}

${ }^{a}$ CF well-preserved montane cloud forest, PF peri-urban forest, UF urban forest, CS shade coffee plantation, PS cattle field, C species code

\section{Assemblage structure}

In general, there is a higher evenness during the dry season in comparison to the other two seasons. Moreover, whereas $\mathrm{CF}, \mathrm{PF}$, and UF have the highest species richness across the year, CS and PS have the lowest (Fig. 2). The highest mosquito numbers and strong community dominance were observed during the rainy season due to the high abundances of Aedes quadrivittatus and Wyeomyia adelpha (Fig. 2), such dominance is reflected in the lowest species richness during this season. Strong community dominance during the cold season by the same two mosquito species mentioned above was also detected (Fig. 2). Furthermore, during the cold season PS presented the highest species richness. Following, detailed results for each season are provided.

During the dry season statistical significant differences in the mosquito assemblage structure were detected between the following pairs of land uses: CF- PF regarding abundance, PF-UF and PF- CS regarding abundance and richness (Table 3, Fig. 2). Rank-abundance curves showed that the urban forest (UF) is the site with the highest number of species and individuals (7 spp., 278 individuals), followed by

Table 2 General additive mixed model (GAMM) results using a Poisson distribution model. Significant $P$ values are in boldface and non-significant trends in italics

\begin{tabular}{|c|c|c|c|c|c|c|c|c|}
\hline \multirow[b]{2}{*}{ Components } & \multicolumn{4}{|c|}{ Abundance } & \multicolumn{4}{|l|}{ Richness } \\
\hline & Estimate & SE & $t$-value & $P$-value & Estimate & SE & $t$-value & $P$-value \\
\hline Intercepts & 3.918 & 0.243 & 16.107 & 0.000 & 0.798 & 0.187 & 4.263 & 0.000 \\
\hline Rainy & 0.340 & 0.235 & 1.284 & 0.202 & 0.154 & 0.235 & 0.656 & 0.513 \\
\hline Dry & -0.642 & 0.221 & -1.863 & 0.065 & 0.442 & 0.221 & 2.000 & 0.048 \\
\hline Peri-urban Forest (PF) & -2.190 & 0.273 & -3.433 & 0.001 & -0.406 & 0.273 & -1.488 & 0.140 \\
\hline Urban Forest (UF) & -3.268 & 0.288 & -3.093 & 0.003 & -0.588 & 0.288 & -2.038 & 0.044 \\
\hline Coffe Plantation (CS) & -3.045 & 0.311 & -3.207 & 0.002 & -0.811 & 0.311 & -2.610 & 0.010 \\
\hline Cattle Field (PS) & -3.207 & 0.280 & -3.126 & 0.002 & -0.493 & 0.280 & -1.760 & 0.081 \\
\hline Rainy:PF & 1.588 & 0.347 & 2.270 & 0.025 & 0.619 & 0.347 & 1.785 & 0.077 \\
\hline Dry:PF & 1.367 & 1.785 & 1.680 & 0.096 & 0.406 & 0.335 & 1.209 & 0.229 \\
\hline Rainy:UF & 1.994 & 0.335 & 1.783 & 0.077 & 0.721 & 0.362 & 1.994 & 0.049 \\
\hline Dry:UF & 3.497 & 0.362 & 3.121 & 0.002 & 0.690 & 0.346 & 1.995 & 0.049 \\
\hline Rainy:CS & 2.178 & 0.346 & 2.178 & 0.032 & 0.902 & 0.381 & 2.366 & 0.020 \\
\hline Dry:CS & 1.672 & 0.381 & 1.474 & 0.143 & 0.251 & 0.386 & 0.651 & 0.517 \\
\hline Rainy:PS & -0.229 & 0.386 & -0.162 & 0.871 & -0.355 & 0.404 & -0.878 & 0.382 \\
\hline Dry:PS & 0.753 & 0.404 & 0.528 & 0.599 & -0.442 & 0.382 & -1.156 & 0.250 \\
\hline
\end{tabular}




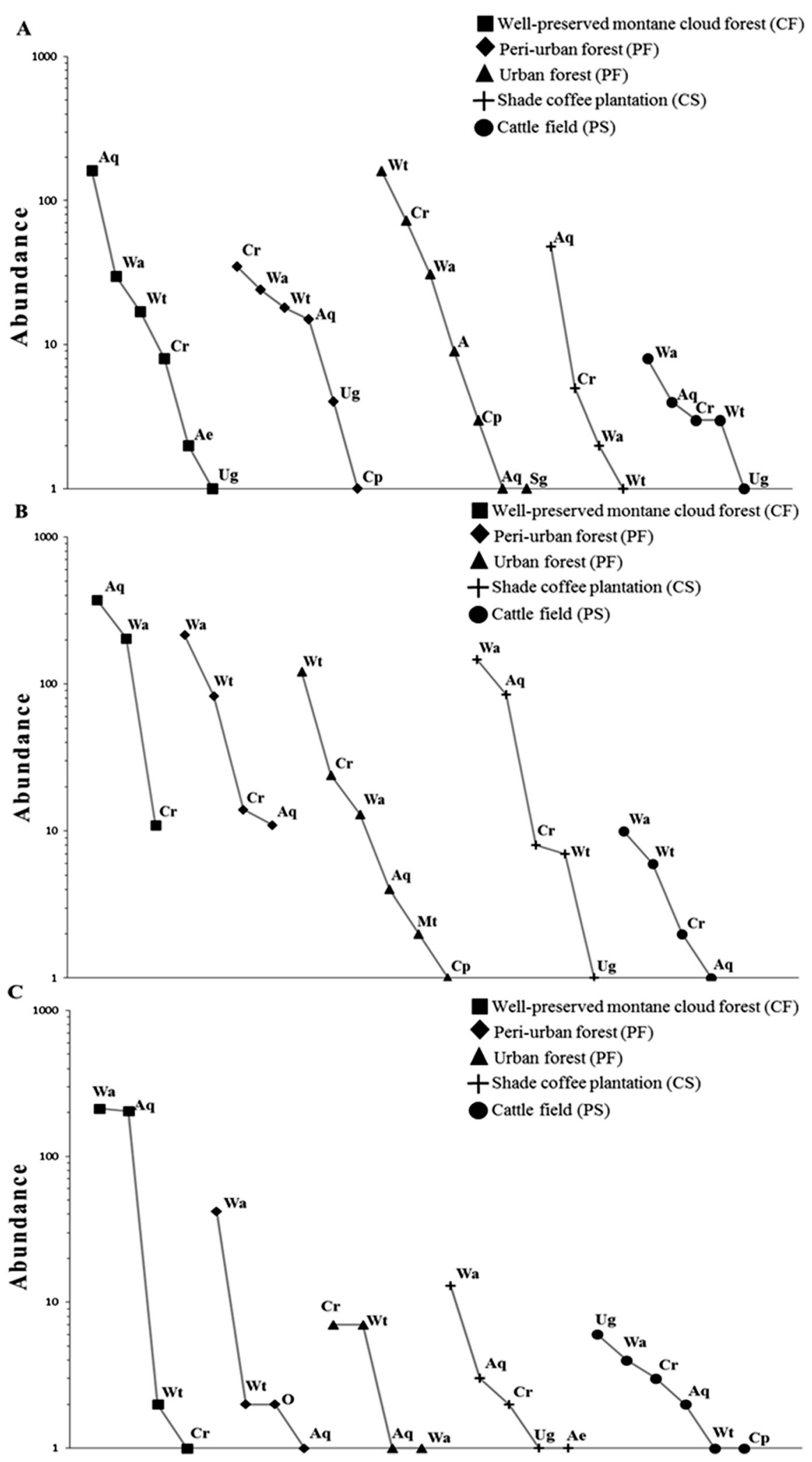

Fig. 2 Rank-abundance curves of mosquito species captured at each site (well-preserved montane cloud forest (CF), peri-urban forest (PF), urban forest (UF), shade coffee plantation (CS) and cattle field (PS)) and seasons: a) dry, b) rainy, and c) cold. Species codes are shown in Table 1 
Table 3 Covariance analyses (ANCOVAs) comparing slopes of rank-abundance curves among land-use types and seasons. Significant $P$ values are in boldface

\begin{tabular}{|c|c|c|c|c|}
\hline \multicolumn{5}{|c|}{ Dry } \\
\hline & ${ }^{\mathrm{a}} \mathrm{CF}$ & $\mathrm{PF}$ & UF & CS \\
\hline CF & $\ldots$ & $\ldots$ & $\ldots$ & \\
\hline PF & $\mathrm{F}_{1,35}=0.720 ; P=3.62 \mathrm{e}-07$ & $\ldots$ & $\ldots$ & $\ldots$ \\
\hline UF & $F_{1,22}=0.034 ; P=0.249$ & $\mathrm{~F}_{1,25}=0.247 ; P=4.364 \mathrm{e}-06$ & $\ldots$ & $\ldots$ \\
\hline CS & $F_{1,21}=0.089 ; P=0.089$ & $F_{1,24}=0.311 ; P=9.758 \mathrm{e}-06$ & $F_{1,11}=0.013 ; P=0.307$ & $\ldots$ \\
\hline PS & $F_{1,18}=0.002 ; P=0.782$ & $F_{1,21}=0.003 ; P=0.462$ & $F_{1,9}=0.011 ; P=0.160$ & $F_{1,7}=0.026 ; P=0.208$ \\
\hline \multicolumn{5}{|c|}{ Rainy } \\
\hline & $\mathrm{CF}$ & $\mathrm{PF}$ & UF & CS \\
\hline CF & $\ldots$ & $\ldots$ & $\ldots$ & \\
\hline PF & $\mathrm{F}_{1,35}=0.541 ; P=8.433 \mathrm{e}-09$ & $\ldots$ & $\ldots$ & $\ldots$ \\
\hline UF & $\mathrm{F}_{1,33}=0.364 ; P=8.203 \mathrm{e}-06$ & $F_{1,36}=0.009 ; P=0.393$ & $\ldots$ & $\ldots$ \\
\hline CS & $F_{1,30}=0.016 ; P=0.151$ & $F_{1,33}=0.265 ; P=1.310 \mathrm{e}-06$ & $F_{1,31}=0.169 ; P=0.0005$ & $\ldots$ \\
\hline PS & $F_{1,17}=0.074 ; P=0.013$ & $F_{1,20}=0.110 ; P=0.002$ & $F_{1,18}=0.105 ; P=0.018$ & $F_{1,15}=0.081 ; P=0.001$ \\
\hline \multicolumn{5}{|c|}{ Cold } \\
\hline & $\mathrm{CF}$ & $\mathrm{PF}$ & UF & CS \\
\hline CF & $\ldots$ & $\ldots$ & $\ldots$ & $\ldots$ \\
\hline $\mathrm{PF}$ & $F_{1,18}=0.001 ; P=0.692$ & $\ldots$ & $\ldots$ & $\ldots$ \\
\hline UF & $\mathrm{F}_{1,16}=0.083 ; P=0.009$ & $\mathrm{~F}_{1,8}=0.075 ; P=0.013$ & $\ldots$ & $\ldots$ \\
\hline CS & $F_{1,13}=0.210 ; P=0.0007$ & $F_{1,5}=0.202 ; P=0.006$ & $\mathrm{~F}_{1,3}=0.262 ; P=0.004$ & $\ldots$ \\
\hline PS & $F_{1,15}=0.016 ; P=0.214$ & $F_{1,7}=0.018 ; P=0.168$ & $F_{1,5}=0.004 ; P=0.340$ & $F_{1,2}=0.227 ; P=0.013$ \\
\hline
\end{tabular}

${ }^{a} C F$ well-preserved montane cloud forest, $P F$ peri-urban forest, UF urban forest, CS shade coffee plantation, $P S=$ cattle field

the well-preserved montane cloud forest (CF) (6 spp., 221 individuals), the peri-urban forest (PF) (6 spp., 97 individuals), cattle field (PS) (5 spp., 19 individuals) and shade coffee plantation (CS) (4 spp., 56 individuals; Fig. 2). Four species were present in the five sites: Aedes quadrivittatus, Culex restuans, Wyeomyia adelpha and Wy. arthrostigma, with different abundance hierarchy. Uranotaenia geometrica was present only in three sites (CF, PF, and CS), Coquillettidia perturbans only in PF and UF, and Sabethes gymnothorax in UF (Fig. 2).

Rank-abundance curves during the rainy season had the following general features: CF (3 spp., 590 individuals), UF (6 spp., 165 individuals), CS (5 spp., 248 individuals), PF (4 spp., 323 individuals), and PS (4 spp., 19 individuals, Fig. 2). There were significant differences in the mosquito assemblage regarding abundance and richness between CF-PF, CF-UF, CF-PS, PF-CS, UF-CS, UF-PS and CS-PS (Table 3). For the PF-PS pair, the obtained difference was only in reference to abundance (Table 3). Three species were present at all land-use types: Aedes quadrivittatus, Culex restuans and Wyeomyia adelpha, but with different abundances. Wyeomyia arthrostigma was not present in CF; Cq. perturbans and Mansonia titillans were found only in UF, whereas Ur. geometrica was found exclusively in CS (Fig. 2).
Rank-abundance curves during the cold season had the following general features: CF (4 spp., 420 individuals), PS (6 spp., 17 individuals), CS (5 spp., 20 individuals), PF (4 spp., 47 individuals), and UF (4 spp., 16 individuals), it is important to notice the large difference in total abundance between the CF and the other sites during this season. There were significant differences in the mosquito assemblage when considering both species richness and abundance between CF-UF, CF-CS, PF-US, UF-CS, and CS-PS (Table 3). Aedes quadrivittatus and Wyeomyia adelpha were present in all land-use types, $W$. arthrostigma was absent in $\mathrm{C}$, and $\mathrm{Cx}$. restuans was absent in PF. Anopheles eiseni was found exclusively in CS, Cq. perturbans in PS, and Ur. geometrica in CS and PS, In the UF, Sabethes gymnothorax was captured in the dry season and $M a$. titillans was only collected in the rainy season (Fig. 2).

\section{Species composition}

The cluster analysis for species incidences $\left(1-\beta_{\text {sim }}\right)$ shows that there is a high degree of similarity in species numbers across sites and seasons throughout the year, virtually the same mosquito species are found across the studied landscape (Fig. 3). Clusters integrated by CS, PS, and PF during the dry season, by CF, PF and PS during the rainy season, and by CF and UF during the cold season had $100 \%$ 

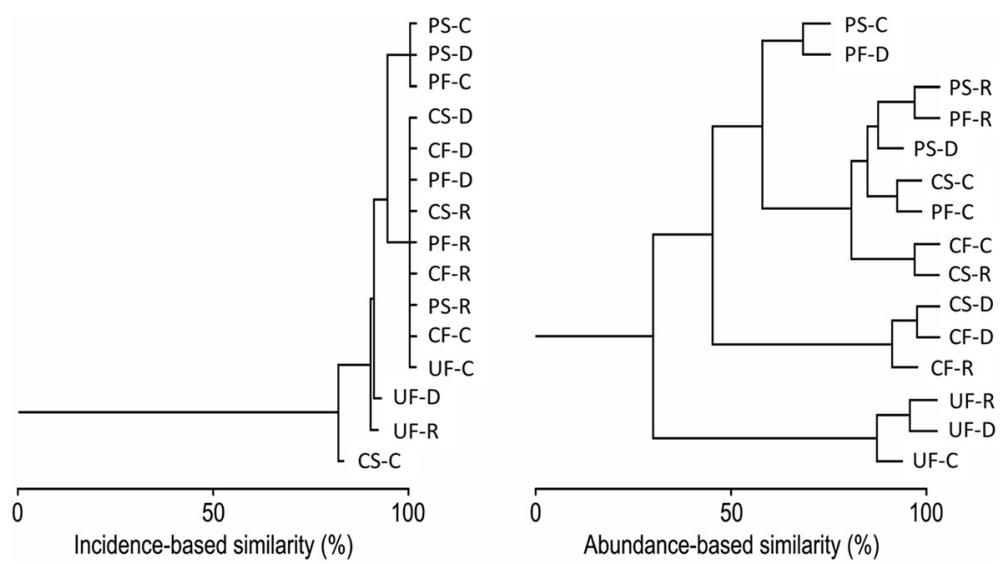

Fig. 3 Dendrograms of cluster analyses showing similarities based on incidence (1-B $\left.\mathrm{B}_{\text {sim }}\right)$ and on species abundances (Morisita-Horn). Scales at the bottom of the figure represent similarity values (\%). Sites: well-preserved montane cloud forest (CF), peri-urban forest (PF), urban forest (UF), shade coffee plantation (CS) and cattle field (PS); seasons: dry (D), rainy (R) and cold (C)

species similarity (Fig. 3). The conditions with less similarity in species richness were CS during the cold season (83\%), and by UF during the dry and rainy seasons (>94 \%, Fig. 3).

The cluster analysis based on the Morisita-Horn abundance index showed higher variation and lower similarity across sites and seasons in comparison to species composition (Fig. 3). There are four clusters with a high degree of similarity $(>70 \%)$ within themselves, but with low similarity ( $<35 \%)$ among them (Fig. 3). We identified two clusters with similarity values above $90 \%$; one such cluster represented by UF in all seasons, indicating that this forest is very similar to itself across the year. Aedes quadrivittatus, Culex restuans, Wyeomyia adelpha, Wy. arthrostigma and Coquillettidia perturbans are the species that are driving this similarity pattern. The other cluster with high similarity includes CF during dry and rainy seasons, which are very similar to the shade coffee plantation (CS) during the dry season. The well-preserved cloud forest (CF) mosquito species abundances change during the cold season, making it more similar to CS during the rainy season. Ae. quadrivittatus, Cx. restuans, Wy. adelpha, Wy. arthrostigma, Uranotaenia geometrica and Anopheles eiseni are the species that are driving the similarities between CF and CS. The peri-urban forest (PF) is very similar to CS during the cold season and to PS during the rainy season (Fig. 3). The species driving the similarities among such sites are Ae. quadrivittatus, Cx. restuans, Wy. adelpha and Wy. arthrostigma.

\section{Discussion}

This study focused on understanding responses of a mosquito (Diptera: Culicidae) assemblage to different land-use types throughout the year, within a landscape originally dominated by neotropical montane cloud forest. In general, our results show that the region, regardless of land-use type, is dominated by four species (Aedes quadrivittatus, Wyeomyia adelpha, Wy. arthrostigma, and Culex restuans), and that communities are very similar in terms of species richness: more than half of the species are shared among the five conditions during the three seasons of the year. In terms of abundances, mosquito communities show higher variability and lower similarity among land-use types and seasons, indicating that resources for mosquito development vary across space and time. In particular, the hierarchy of dominant species changes in reference to land-use type and sometimes across seasons within the same habitat type. Wooded areas (e.g., well-preserved montane cloud forests, secondary cloud forests, shade coffee plantations) can account for the similarity of mosquito communities across sites; even cattle ranches in the area are small, with interspersed trees, and surrounded by forests. Furthermore, flying habits of mosquito species (e.g., Ma. titillans and Cq. perturbans, which can fly several miles from their oviposition sites $[28,47])$ can also be responsible for the high species similarity observed. Another important feature is the presence of epiphytes, such as bromeliads across the landscape, which are commonly used by species such as Ae. quadrivittatus and Wy. adelpha for oviposition [27, 38]. Hence, the mosquito assemblage is highly homogeneous across this local landscape, which can be the result of high connectivity provided by a largely forested matrix.

Mosquito species numbers and abundances are known to readily respond to abiotic conditions $[14,16]$. Low temperatures during the cold months of the year are most likely directly affecting mosquito richness and abundance because low temperatures reduce mosquito breeding and feeding activities [48-50]. An interesting aspect is the high composition similarity of the urban forest (UF) throughout the year for both species richness and abundance. Being surrounded by unsuitable habitat (gray areas of xcities) for many mosquito species, the assemblage is isolated from other nearby sites in the landscape, which reduces 
the possibility of dispersal and may explain the relative structural difference in the mosquito assemblage in comparison to the other sampled conditions (e.g., the singleton Sa. gymnothorax, Fig. 3). In contrast, the well-preserved montane cloud forest and the shade coffee plantation are similar in mosquito species. This can be explained by the proximity of both sites as many species of mosquitoes can travel several kilometers to feed in these environments, such as the dominant species Ae. quadrivittatus and Wy. adelpha.

Richness and abundance analyses showed that there is an increase in richness for those environments close to or at the city (i.e., urban and peri-urban forests), but abundance is higher at the well-preserved montane cloud forest. Richness and abundance do not always decrease progressively or vary in parallel with increasing habitat modification $[51,52]$. Forest disturbance apparently cause an increase in species richness; as an example, some studies have shown that species richness of dung beetles is higher in logged forests compared to primary forests [53]. Another example is the increase in numbers of nesting bees and wasps as landuse intensity increases [54]. Secondary forests and agroforestry systems probably maintain diversity [51]. Hence, it is necessary to delve further in the relevance of human dominated habitats, in particular urban ones that will be more common in the near future, for both to understand how they help protect biodiversity and also how they disrupt host-parasite interactions in such a way that wildlife pathogens can become a health issue [55-57].

The urban environment may have a negative influence on biodiversity due to the generated isolation by gray areas (buildings and roads), pollution, and the use of insecticides [58]. In such conditions, only mosquito species that can adapt will increase their abundances. For example, females of Ae. quadrivittatus are attracted to humans; they are able to feed throughout the day, and viruses have been isolated from this species in Panama [59]. Wy. arthrostigma is the most abundant species in the urban forest, this may be due to the ability of this species to use holes in trees and hollow shafts for oviposition [60], favored by the presence of bamboo patches, which is one of the preferred oviposition sites. In the case of $C x$. restuans, the larvae develop in a wide xvariety of water sources such as ditches, pools, streams, forests, and artificial reservoirs (e.g., tires, cans, fountains). This species reaches its highest abundance during the spring and early summer throughout most of its range, and occurs in fewer numbers during late summer and autumn $[29,61]$. At our study sites, this species had higher abundance in the urban forest. Several studies have demonstrated the ability of $C x$. restuans to transmit avian malaria [62-65], which can represent a health risk for native birds using these forest remnants within cities. Furthermore, among the species of medical importance are Mansonia titillans, which is vector of Venezuelan equine encephalitis virus (VEE), it was the primary vector for the 1942-1943 epidemic in Trinidad. This species is known to be a vector of filarid nematodes as well [29]. The females of Coquillettidia perturbans bite mainly at night, usually more active during the first hours of the night. Occasionally, it bites humans during the day inside houses and is a vector of eastern equine encephalitis (EEE) [66]. The latter two species are rare at our study sites, but the individuals we collected were mainly from the urban forest. Hence, it is likely that humans and other wild vertebrates using this type of environment will be at higher risk of infection by the above-mentioned parasite groups, in particular considering that wild host populations (i.e., urban avoiders restricted to green areas of cities) are packed within relatively small areas.

Some mosquito species exhibit a high degree of specialization in their host and oviposition site selection, while others are completely generalist and opportunistic [67-69]. Changes in host abundances due to anthropogenic impacts can affect both host and habitat choice, especially if blood-sucking species are generalists and mobile (e.g., $[15,16,70])$. The peri-urban forest and the cattle field had the same mosquito assemblage structure during the rainy season, but with different abundances; forest fragments and urban areas are bordering the cattle field, providing similar anthropogenic influences for both sites. It is possible that mosquitoes use the cattle field as a feeding site because it provides food all year round due to the presence of domestic animals, such as cows and chickens; at the same time, it provides shelter because of the presence of nearby forest fragments and secondary vegetation [70]. Hence, it is necessary that future studies consider sampling a buffer of the surrounding habitat to the focal one, in order to have a better understanding of mosquito community spatial and temporal dynamics.

Analyzing richness and abundance of mosquito assemblages separately can be a better strategy to identify differences under similar environmental conditions in comparison to the use of diversity indexes. Land-use change and habitat alteration have consequences in mosquito vector assemblage structure. Mosquito diversity studies, as the one presented here, represent an important first step for planning urban development in terms of sanitarian strategies for vector-borne disease prevention, as well as developing surveillance programs to prevent zoonotic disease. Finally, mosquito community studies can be useful to monitor ecosystem health [71].

\section{Conclusions}

This study showed that land-use changes and seasonality influence mosquito community structure, in particular in terms of species abundances. However, our results also demonstrate that the mosquito assemblage is rather homogeneous (i.e., highly similar richness) across the studied 
landscape, suggesting a high degree of spatial connectivity, even when land-use types represent a drastic change (e.g., cattle ranches) compared to the original cloud forest. Near the city environments mosquito richness is greater than at the well-preserved cloud forest, but the later has higher abundance compared to all other sites. The highest species richness was recorded during the dry season, but the highest abundance was recorded during the rainy season. Finally, our work generates important information to understand mosquito diversity in reference to land-use changes within landscapes, which is a potentially useful tool in the development of urban planning and surveillance programs focused mainly on mosquito species of medical and veterinary importance.

\section{Additional file}

Additional file 1: Species accumulation curve to assess sampling effort, showing that $100 \%$ of the species were obtained in the present study. (PNG $89 \mathrm{~kb}$ )

\section{Abbreviations}

CF: Well-preserved montane cloud forest; PF: Peri-urban forest; UF: Urban forest; CS: Shade coffee plantation; PS: Cattle field; VEE: Venezuelan equine encephalitis virus; EEE: Eastern equine encephalitis; ACE: Abundance-based coverage estimator; GAMM: Generalized additive mixed models.

\section{Competing interests}

The authors declare that they have no competing interests.

\section{Authors' contributions}

CA-M, SI-B and DS-A conceived and designed the study and performed the experiments. CA-M and SI-B identified specimens and built the database. CA-M, IM-F and DS-A performed statistical analyses. CA-M, SI-B, DS-A and IM-F wrote the manuscript; all authors provided relevant input at different stages of manuscript preparation. All authors read and approved the final manuscript.

\section{Acknowledgements}

We thank R. Gonzalez-Trapaca, C. Domínguez-Rodríguez, A. C. Montes de Oca-Aguilar and J. J. Von Thaden Ugalde for their assistance during fieldwork. We thank landowners (Don Félix, Don Albino, Don Hernan, and F. Cervantes) for allowing us to work in their private properties.

\section{Financial suppport}

Diego Santiago-Alarcon and Sergio Ibañez-Bernal were supported by Consejo Nacional de Ciencia y Tecnología (CONACYT, project number CB-2011-01-168524), Carlos Antonio Abella-Medrano was supported by a doctorate degree grant (CONACYT, scholarship number 335647). INECOL provided support through an academic retreat program. Sampling permit number SGPADGVS/05057/13 was provided by Secretaría de Medio Ambiente y Recursos Naturales (SEMARNAT).

\footnotetext{
Author details

${ }^{1}$ Instituto de Ecología A.C., Red Ambiente y Sustentabilidad, Carretera antigua a Coatepec 351 El Haya, Xalapa 91070, Veracruz, Mexico. ${ }^{2}$ Instituto de Ecología A.C., Red de Biología y Conservación de Vertebrados, Carretera antigua a Coatepec 351 El Haya, Xalapa 91070, Veracruz, Mexico.
}

Received: 7 July 2015 Accepted: 11 September 2015 Published online: 24 September 2015

\section{References}

1. Didham RK, Ghazoul J, Stork NE, Davis AJ. Insects in fragmented forests: a functional approach. Trends Ecol Evol. 1996;11:255-60.
2. Lambin EF, Turner BL, Geist HJ, Agbola SB, Angelsen A, Bruce JW, et al. The causes of land-use and land-cover change: moving beyond the myths. Global Environ Chang. 2001;11:261-9.

3. Tylianakis JM, Didham RK, Bascompte J, Wardle DA. Global change and species interactions in terrestrial ecosystems. Ecol Lett. 2008;11:1351-63.

4. Boren JC, Engle DM, Palmer MW, Masters RE, Criner T. Land use change effects on breeding bird community composition. J Range Manage. 1999;52:420-30.

5. Posa MRC, Sodhi NS. Effects of anthropogenic land use on forest birds and butterflies in Subic Bay, Philippines. Biol Conserv. 2006;129:256-70.

6. Lutolf M, Guisan A, Kienast F. History matters: relating land-use change to butterfly species occurrence. Environ Manage. 2009:43:436-46.

7. Blaum N, Rossmanith $E$, Jeltsch F. Land use affects rodent communities in Kalahari savannah rangelands. Afr J Ecol. 2007;45:189-95.

8. Foley JA, DeFries R, Asner GP, Barford C, Bonan G, Carpenter SR, et al. Global consequences of land use. Science. 2005;309:570-4.

9. Amerasinghe F, Ariyasena T. Larval survey of surface water-breeding mosquitoes during irrigation development in the Mahaweli Project. Sri Lanka. J Med Entomol. 1990;27:789-802.

10. Matthys B, N'Goran EK, Kone M, Koudou BG, Vounatsou P, Cisse G, et al. Urban agricultural land use and characterization of mosquito larval habitats in a medium-sized town of Cote d'Ivoire. J Vector Ecol. 2006;31:319-33.

11. Vanwambeke SO, Lambin EF, Eichhorn MP, Flasse SP, Harbach RE, Oskam L, et al. Impact of land-use change on dengue and malaria in northern Thailand. Ecohealth. 2007:4:37-51.

12. Norris DE. Mosquito-borne diseases as a consequence of land use change. Ecohealth. 2004;1:19-24.

13. Chang M, Hii J, Buttner P, Mansoor F. Changes in abundance and behaviour of vector mosquitoes induced by land use during the development of an oil palm plantation in Sarawak. Trans R Soc Trop Med Hyg. 1997;91:382-6.

14. Lindblade KA, Walker ED, Onapa AW, Katungu J, Wilson ML. Land use change alters malaria transmission parameters by modifying temperature in a highland area of Uganda. Trop Med Int Health. 2000;5:263-74.

15. Santiago-Alarcon D. Havelka P. Schaefer HM. Segelbacher G. Bloodmeal analysis reveals avian Plasmodium infections and broad host Dreferences of Culicoides (Diptera: Ceratopogonidae) vectors. PLoS ONE 7: e31098. doi:10.1371/journal.pone.0031098

16. Santiago-Alarcon D, Havelka P, Pineda E, Seaelbacher G, Schaefer H. Urban forests as hubs for novel zoonosis: blood meal analvsis. seasonal variation in Culicoides (Diptera: Ceratopogonidae) vectors, and avian haemosporidians. Parasitology. 2013;140:1799-810.

17. Tolome J. Caida de hojarasca y comportamiento fenológico de las especies arboreas del bosque mesofilo de montana del Parque Ecológico Francisco X. Clavijero. Xalapa. Veracruz. Mexico: Bachelor thesis, Universidad Veracruzana; 1993;74.

18. Williams-Linera G. Vegetación de bordes de un bosque nublado en el Parque Ecologico Clavijero, Xalapa. Veracruz. Mexico. Rev Biol Trop. 1993:41:1 07-117.

19. Williams-Linera G. El bosque de niebla del centro de Veracruz: ecología. historia y destino en tiempos de fragmentacion y cambio climatico. Xalapa: CONABIO-Instituto de Ecologia A.C; 2007;208

20. Contreras PS, Ornelas JF. Reproductive conflicts of Palicourea padifolia (Rubiaceae) a distylous shrub of a tropical cloud forest in Mexico. Plant Syst Evol. 1999;219:225-41.

21. Garcia-De la Cruz Y, Olivares-Lopez LA, Ramos-Prado JM. Estructura y composicion arborea de un fragmento de bosque mesofilo de montana en el estado de Veracruz. Rev Chapingo Ser Cie. 2013;19:91-101.

22. Lopez-Moreno I. Ecologia Urbana aplicada a la Ciudad de Xalapa. H. Ayuntamiento de Xalapa y Programa MAB UNESCO, Xalapa: Instituto de Ecologia; 1993;258.

23. Vazquez-Torres SM, Carvajal-Hernandez Cl, Aquino-Zapata AM. Areas naturales protegidas. In: Bedtez- Badillo G, Welsh-Rodnguez C, editors. Atlas del patrimonio natural, historico y cultural de Veracruz, Vol. 1. Xalapa, Veracruz: Patrimonio natural, Comision del Estado de Veracruz para la Conmemoracion de la Independencia Nacional y de la Revolucion Mexicana, Gobierno del Estado de Veracruz-Universidad Veracruzana; 2010;249-74.

24. Lopez-Gomez AM. Los cafetales de sombra como reservorio de la biodiversidad de plantas lenosas del bosque mesofilo de montana del centra de Veracruz. Xalapa, Veracruz. Mexico: Master thesis, Instituto de Ecologia A.C; 2004;81. 
25. Muniz-Castro MA, Williams-Linera G, Benayas JMR. Distance effect from cloud forest fragments on plant community structure in abandoned pastures in Veracruz. Mexico. J Trop Ecol. 2006;22:431-40.

26. Harbach RE, Knight KL. Taxonomists' glossary of mosquito anatomy. Marlton, New Jersey: Plexus Publishing Inc; 1980;415.

27. Berlin OGW. Mosquito studies (Diptera, Culicidae) XII. A revision of the neotropical subgenus Howardina of Aedes. Estudios sobre zancudos (Diptera, Culicidae) XII. Revision del genero neotropical Howardina de Aedes. Contributions of the AEl. 1969;4:1-190.

28. Lane J. Neotropical Culicidae. Brazil: Volumes I \& II. Published by the University of Sao Paulo; 1953;1112.

29. Carpenter SJ, LaCasse WJ. Mosquitoes of North America: University of California Press; 1965;360.

30. McAlpine JF, Peterson BV, Shewell G, Teskey H, Vockeroth J, Wood D. Manual of Nearctic Diptera: Volume 1. Research Branch. Agriculture Canada. Monographs. 1981;27:674.

31. Brown BV. Borkent A. Cummina JM. Wood DM. Woodlev NE. Zumbado M. Manual of Central American Diptera: Volume 1. Canadian Science Publishing (NRC Research Press): 2009;714.

32. Galindo P, Blanton FS, Peyton E. A revision of the Uranotaenia of Panama with notes on other American species of the genus (Diptera, Culicidae). Ann Entomol Soc Am. 1954;47:107-77.

33. Belkin JN, Heinemann SJ, Page WA. The Culicidae of Jamaica. Institute of Jamaica (Mosquito Studies. XXI). Contributions of the American Entomological Institute. 1970;6:1-458.

34. Ronderos RA, Bachmann AO. 1963. Mansoniini Neotropicales. I (Diptera: Culicidae). Rev Soc Entomol Argent. 1963:26:57-65.

35. Harbach RE, Petersen JL. Two species previously confused under the concept of Sabethes tarsopus in Central America (Diptera: Culicidae). Mosa Syst. 1992;24:102-24

36. Colwell RK, Coddington JA. Estimating terrestrial biodiversity through extrapolation. Philos T R Soc B. 1994;345:101-18.

37. Magurran AE. Measuring biological diversity. John Wiley \& Sons. 2003;264.

38. Moreno C. Métodos para medir la biodiversidad. Zaragoza: Manuales y Tesis Sociedad Entomológica Aragonesa; 2001;83.

39. Villareal H, Alvarez M, Cordoba S, Escobar F, Fagua G, Gast F, et al. Manual de metodos para el desarrollo de inventarios de biodiversidad. Programa de Inventarios de Biodiversidad. Bogota, Colombia: Instituto de Investigacion de Recursos Biologicos Alexander von Humboldt; 2004;236.

40. Colwell RK. Estimates. Statistical estimation of species richness and shared species from samples. 2013. http://vicerov.eeb.uconn.edu/estimates/ Accessed 14 Sep 2015

41. Zuur A, leno EN, Walker N, Saveliev AA, Smith GM. Mixed effects models and extensions in ecology with R: Springer Science \& Business Media: 2009;574.

42. Wood S. Generalized additive models: an introduction with R: Chapman Hall/CRC press; 2006;410

43. Pinheiro J, Bates D, DebRoy S, Sarkar D. Linear and nonlinear mixed effects models. R package version 3. 57. 2007. httDs://cran.r-Droiect.ora/web/ Dackaaes/nlme/index.html. Accessed 14 Sep 2015.

44. Bates D, Maechler M, Bolker B. Ime4: Linear mixed-effects models using S4 classes. R package. version 0.999375-8. 2012. https://cran.rproject.org/web/ packages/Ime4/index.html. Accessed 14 Sep 2015.

45. Sarkar D. Lattice: multivariate data visualization with R: Springer Science \& Business Media; 2008;268.

46. Ortega-Alvarez R, MacGreaor-Fors I. Living in the big city: effects of urban land-use on bird community structure, diversity. and composition. Landscape Urban Plan. 2009;90:189-95.

47. Lennon JJ, Koleff P, Greenwood J, Gaston KJ. The geographical structure of British bird distributions: diversity. spatial turnover and scale. J Anim Ecol. 2001;70:966-79.

48. Lounibos L, Linley J. A Quantitative analysis of underwater oviposition by the mosquito Mansonia titillans. Physiol Entomol. 1987;12:435-43.

49. Thu HM, Aye KM, Thein S. The effect of temperature and humidity on dengue virus propagation in Aedes aegypti mosquitos. Se Asian J Trop Med. 1998;29:280-4

50. Angel B, Joshi V. Distribution and seasonality of vertically transmitted dengue viruses in Aedes mosquitoes in arid and semi-arid areas of Rajasthan. India J Vect Dis. 2008:45:56
51. Beck J, Schulze CH, Linsenmair KE, Fiedler K. From forest to farmland: diversity of geometrid moths along two habitat gradients on Borneo. J Trop Ecol. 2002;18:33-51.

52. Costa F, Magnusson W. Selective logging effects on abundance, diversity, and composition of tropical understory herbs. Ecol Appl. 2002;12:807-19.

53. Davis AJ, Holloway JD, Huijbregts H, Krikken J, Kirk-Spriggs AH, Sutton SL. Dung beetles as indicators of change in the forests of northern Borneo. J Appl Ecol. 2001;38:593-616.

54. Klein AM, Steffan-Dewenter I, Buchori D, Tscharntke T. Effects of land-use intensity in tropical agroforestry systems on coffee flower-visiting and trapnesting bees and wasps. Conserv Biol. 2002;16:1003-14.

55. Bradley CA, Altizer S. Urbanization and the ecology of wildlife diseases Trends Ecol Evol. 2007:22:95-102.

56. Alcaide M, Rico C, Ruiz S, Soriguer R, Munoz J, Figuerola J. Disentangling vector-borne transmission networks: a universal DNA barcoding method to identify vertebrate hosts from arthropod bloodmeals. PLOS ONE. 2009:4:e7092. doi:10.1371/journal.pone.0007092.

57. Keesing F, Belden LK, Daszak P, Dobson A, Harvell CD, Holt RD, et al. Impacts of biodiversity on the emergence and transmission of infectious diseases. Nature. 2010;468:647-52.

58. Alberti M. Advances in urban ecology: integrating humans and ecological processes in urban ecosystems. New York: Springer; 2008;366.

59. Ortega Morales Al. Los mosquitos del noreste de Mexico (Diptera: Culicidae). PhD thesis, Autonomous University of Nuevo Leon: 2010;250.

60. Navarro JC, Machado-Allison C. Aspectos ecologicos de Sabethes chloropterus (Humboldt) (Diptera: Culicidae) en un bosque humedo del Edo. Miranda. Venezuela. Bol Entomol Venez. 1995;10:91-104.

61. Strickman D, Darsie Jr RF. The previously undetected presence of Culex restuans (Diptera: Culicidae) in Central America, with notes on identification. Mosq Syst. 1988;20:20-7.

62. Beier JC, Stoskopf M. The epidemiology of avian malaria in black-footed penguins (Spheniscus demersus). J Zoo Anim Med. 1980;11:99-105.

63. Nayar J, Knight J, Telford Jr S. Vector ability of mosquitoes for isolates of Plasmodium elongatum from raptors in Florida. J Parasitol. 1998;84:542-6.

64. Kimura M, Darbro J, Harrington L. Avian malaria parasites share congeneric mosquito vectors. J Parasitol. 2010;96:144-51.

65. Medeiros MC, Hamer GL, Ricklefs RE. Host compatibility rather than vectorhost-encounter rate determines the host range of avian Plasmodium parasites. Proc R Soc Lond B Biol Sci. 2013;280:1-8.

66. Turell MJ, Dohm DJ, Sardelis MR, O'Quinn ML, Andreadis TG, Blow JA. An update on the potential of North American mosquitoes (Diptera: Culicidae) to transmit West Nile virus. J Med Entomol. 2005:42:57-62.

67. Bentley MD, Day JF. Chemical ecology and behavioral aspects of mosquito oviposition. Annu Rev Entomol. 1989:34:401-21.

68. Clements A. The biology of mosquitoes. Vol. I: Development, nutrition and reproduction. CABI Publishina: 1992. 532.

69. Santiago-Alarcon D, Palinauskas V, Schaefer HM. Diptera vectors of avian Haemosporidian parasites: untangling parasite life cycles and their taxonomy. Biol Rev. 2012;87:928-64.

70. Takken W, Verhulst NO. Host preferences of blood-feeding mosquitoes. Annu Rev Entomol. 2013;58:433-53.

71. Patz JA, Daszak P, Tabor GM, Aguirre AA, Pearl M, Epstein J, et al. Unhealthy landscapes: policy recommendations on land use change and infectious disease emergence. Environ Health Persp. 2004;112:1092-8.

\section{Submit your next manuscript to BioMed Central and take full advantage of:}

- Convenient online submission

- Thorough peer review

- No space constraints or color figure charges

- Immediate publication on acceptance

- Inclusion in PubMed, CAS, Scopus and Google Scholar

- Research which is freely available for redistribution 